Dept. of Bacteriology,

Faculty of Veterinary Medicine, Zagazig University.

\title{
BACTERIOLOGICAL STUDIES ON SALMONELLA ENTERITIDIS ISOLATED FROM DIFFERENT SOURCES IN DAKHLIA GOVERNORATE
}

(With 4 Tables)

\author{
By \\ A.M.A. AMMAR; Y. A.EL-G. AHMED \\ A.M.I. ASAWY* and AMIRA AWAD IBRAHIM* \\ * Dept. of Immunology, Animal Health Research Institute, \\ Mansoura Laboratory \\ (Received at 17/10/2009)
}

دراسات بكتريولوجية على سالمونيلا انتريتيدس المعزولة من مصادر مختلفة

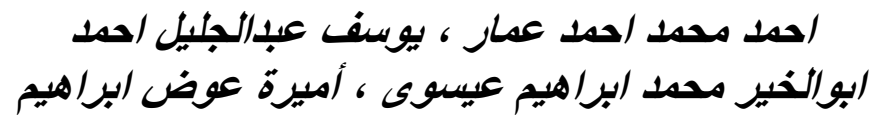

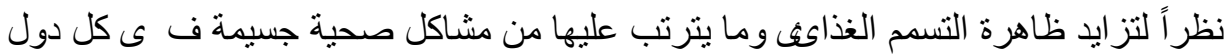

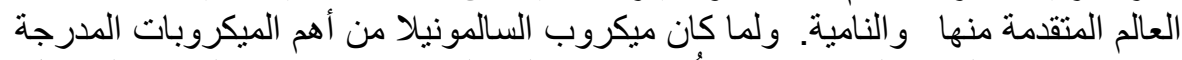





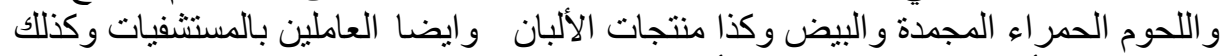



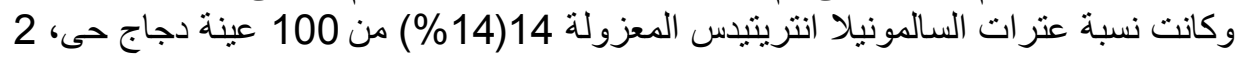

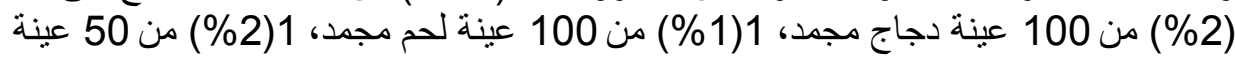

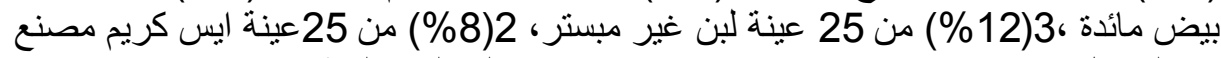

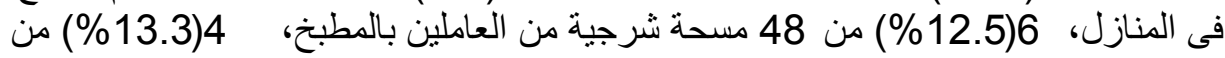

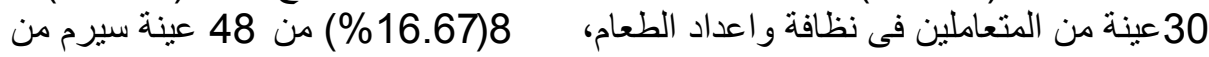
اشخاص يعانون من اعر اضن نسمم غذائى.

\section{SUMMARY}

Foodborne diseases are a widely spreading and growing public health problem, in both developed and developing countries. Salmonella microorganisms are one of the most important causative agents of food poisoning, so this study was planned to determine the incidence of 
Salmonella enteritidis in 546 samples from different sources of animal origin as live poultry, eggs, poultry meat, beef meat and milk products, and also of human origin as food handlers and patients suffering from food poisoning. Detection of Salmonella enteritidis antibodies in patient serum was detected by ELISA .Fourteen strains (14\%) of S.enteritidis were isolated from 100 samples of live poultry, 2 strains $(2 \%)$ from 100 samples frozen poultry, 1 strain $(1 \%)$ from 100 samples frozen meat, 1 strain (2\%) from 50 egg samples, 3 strains (12\%) from 25 unpasteurized raw milk samples, 2 strains (8\%)from 25 home made ice-cream samples, 6 strains $(12.5 \%)$ from 48 stool samples of food poisoning people and 4 strains $(13.3 \%)$ from food handlers. The results of ELISA proved that 8 $(16.67 \%)$ of 48 serum samples had S.enteritidis antibodies.

Key words: Salmonella enteritidis, poultry, eggs, milk and milk products, ELISA, stool.

\section{INTRODUCTION}

Salmonella is one of the primary causes of human food poisoning throughout the world (Fantasia and Filetici, 1994). Worldwide, salmonellosis is a serious medical and veterinary problem and raises great concern in the food industry. Poultry is the most potential source of Salmonella food poisoning in man. Moreover, contamination of the poultry meat with Salmonella in the poultry slaughterhouses is very important (Ashton, 1990). The dominant type of Salmonella food poisoning was Salmonella typhimurium but since 1982, S.enteritidis has been challenging for the dominance. S.enteritidis carried out by chickens and poultry products is the major source of human intestinal infections (Fantasia and Filetici, 1994). Several serological tests have been developed for the diagnosis of Salmonella infections, the enzyme linked immunosorbent assay (ELISA) had been used especially for the detection of S.enteritidis and Salmonella typhimurium carriers in chicken (Barrow, 1994).

The development of effective vaccines against S.enteritidis for chickens has been hindered by lack of knowledge concerning the immune responses against Salmonella in chickens. In general, the mucosal immune system of the intestine, including mucosal immunoglobulin A "secretory IgA" and associated lymphocytes and leukocytes, forms the first line of defense against S.enteritidis infection. Systemic immune responses, including humoral and cell-mediated responses play important roles in the resistance and clearance of S.enteritidis infection (Zhu et al., 2009). 
This study was planned as attempt to spotlight on estimation of the incidence of Salmonella organisms isolated from different sources of animal origin as live\&frozen poultry, eggs, frozen beef meat, milk and milk products, and also of human origin as food handlers and patients suffering from food poisoning, serotyping of the isolated Salmonella species and identifying the prevalent serotypes causing food poisoning, with a special concern to ELISA in detection of S.enteritidis antibodies and Throwing light on antimicrobial sensitivity for strains of S.enteritidis.

\section{MATERIALS and METHODS}

Table 1: Number, sources and clinical condition of samples collected from Dakahlia governorate

\begin{tabular}{|l|c|c|}
\hline Source & Number & Condition of samples \\
\hline $\begin{array}{l}\text { Stool samples from patients with } \\
\text { food poisoning signs }\end{array}$ & 48 & Apparently sick \\
\hline Blood samples from same patients & 48 & Apparently sick \\
\hline Food handlers' hand swabs & 30 & Apparently normal \\
\hline Live poultry & 100 & Apparently normal \\
\hline Frozen poultry before cooking & 100 & Apparently normal \\
\hline Frozen meat before cooking & 100 & Apparently normal \\
\hline Table eggs & 50 & Apparently normal \\
\hline Milk and milk products & 25 & Apparently normal \\
$\quad$ Raw milk & 25 & Apparently normal \\
$\quad$ Ice-cream & 25 & Apparently normal \\
$\quad$ Soft cheese & 25 & Apparently normal \\
$\quad$ Yoghurt & & \\
\hline Total & 576 & \\
\hline
\end{tabular}

Media: Nutrient agar, MacConkey's agar, XLD agar and sugar media were used for isolation of Salmonella species and identification of the bacterial isolates according to Cruickshank et al. (1975).

Serological typing of Salmonella: The isolates that were preliminarily identified as Salmonella were subjected to serological identification according to Kauffman-White Scheme (Kauffman, 1974).

ELISA: ELISA technique was done to detect S.enteritidis antibody in serum samples from patients suffering from food poisoning using S.enteritidis ELISA kits (IDEXX USA) with S.enteritidis coated ELISA plate according to Hassan et al. (1990). 
Antibiotic susceptibility test: Determination of the susceptibility of the isolated strains to antibiotic discs (oxoid) was adopted using the disc diffusion technique according to Finegold and Martin (1982).

\section{RESULTS}

Table 2: Incidence of Salmonella enteritidis from the examined samples

\begin{tabular}{|l|c|c|c|}
\hline \multirow{2}{*}{ Samples } & \multirow{2}{*}{ Total samples } & \multicolumn{2}{c|}{ Salmonella enteritidis } \\
\cline { 3 - 4 } & & No. & $\%$ \\
\hline Stool samples & 48 & 6 & 12.5 \\
\hline Food handlers & 30 & 4 & 13.3 \\
\hline Live poultry & 100 & 14 & 14 \\
\hline Frozen poultry samples & 100 & 2 & 2 \\
\hline Frozen meat samples & 100 & 1 & 1 \\
\hline Egg samples & 50 & 1 & 2 \\
\hline Raw milk & 25 & 3 & 12 \\
\hline Ice-cream & 25 & 2 & 8 \\
\hline Soft cheese & 25 & - & - \\
\hline Yoghurt & 25 & - & - \\
\hline Total & 528 & 33 & $64.8 \%$ \\
\hline
\end{tabular}

Table 3: Antimicrobial sensitivity test in the examined samples

\begin{tabular}{|l|c|c|c|c|c|c|c|c|c|}
\hline \multirow{2}{*}{ Antibiotics } & \multirow{2}{*}{ Conc. $\mu \mathrm{g}$} & \multicolumn{6}{|c|}{ Percentage of effect on isolated S.enteritidis strains } \\
\cline { 3 - 10 } & & Human & $\begin{array}{c}\text { Food } \\
\text { handlers }\end{array}$ & $\begin{array}{c}\text { Live } \\
\text { poultry }\end{array}$ & $\begin{array}{r}\text { Frozen } \\
\text { poultry }\end{array}$ & $\begin{array}{r}\text { Frozen } \\
\text { meat }\end{array}$ & Egg & $\begin{array}{c}\text { Raw } \\
\text { milk }\end{array}$ & Ice cream \\
\hline Enrofloxacin & 5 & $91.9 \%$ & $85.4 \%$ & $83 \%$ & $81 \%$ & $83.8 \%$ & $83.5 \%$ & $77.4 \%$ & $77 \%$ \\
\hline $\begin{array}{l}\text { Trimethoprim- } \\
\text { sulfamethoxazole }\end{array}$ & 25 & $24 \%$ & $19 \%$ & $12.3 \%$ & $18.7 \%$ & $15.4 \%$ & $21 \%$ & $9.4 \%$ & $17.5 \%$ \\
\hline Ampicillin & 20 & $6 \%$ & $9 \%$ & $8 \%$ & $14.2 \%$ & $5 \%$ & $10 \%$ & $13.6 \%$ & $12.1 \%$ \\
\hline Chloramphenicol & 30 & $52 \%$ & $49 \%$ & $33.7 \%$ & $65 \%$ & $43 \%$ & $41 \%$ & $54 \%$ & $54.2 \%$ \\
\hline Ciprofloxacin & 5 & $93.8 \%$ & $86 \%$ & $87.5 \%$ & $93 \%$ & $83 \%$ & $95.4 \%$ & $88 \%$ & $90.2 \%$ \\
\hline Neomycin & 30 & $61.2 \%$ & $58.3 \%$ & $43.4 \%$ & $48 \%$ & $62.4 \%$ & $73.7 \%$ & $67.8 \%$ & $50.2 \%$ \\
\hline Gentamicin & 10 & $68.6 \%$ & $62.4 \%$ & $73.4 \%$ & $68.5 \%$ & $53.7 \%$ & $68.2 \%$ & $45.7 \%$ & $67.9 \%$ \\
\hline Tetracycline & 30 & $55.4 \%$ & $50.8 \%$ & $52 \%$ & $57.5 \%$ & $43 \%$ & $48.7 \%$ & $8 \%$ & $40.6 \%$ \\
\hline
\end{tabular}


Table 4: Serodiagnosis of Salmonella enteritidis using ELISA.

\begin{tabular}{|c|c|c|c|c|c|}
\hline $\begin{array}{c}\text { No. of } \\
\text { samples }\end{array}$ & $\begin{array}{c}\text { Optical } \\
\text { density }\end{array}$ & $\mathrm{S} / \mathrm{P}$ & $\begin{array}{c}\text { No. of } \\
\text { samples }\end{array}$ & $\begin{array}{c}\text { Optical } \\
\text { density }\end{array}$ & $\mathrm{S} / \mathrm{P}$ \\
\hline 1 & 0.982 & 0.4069 & 25 & 0.772 & 0.2136 \\
\hline 2 & 1.210 & 0.6169 & 26 & 1.285 & 0.6860 \\
\hline 3 & 1.740 & 1.1049 & 27 & 0.848 & 0.2836 \\
\hline 4 & 1.325 & 0.7228 & 28 & 1.395 & 0.7872 \\
\hline 5 & 2.085 & $1.4226^{*}$ & 29 & 1.842 & 1.1988 \\
\hline 6 & 0.985 & 0.4097 & 30 & 1.487 & 0.8720 \\
\hline 7 & 0.762 & 0.2044 & 31 & 2.358 & $1.674^{*}$ \\
\hline 8 & 1.562 & 0.9410 & 32 & 1.185 & 0.5939 \\
\hline 9 & 1.443 & 0.8314 & 33 & 2.796 & $2.0773^{*}$ \\
\hline 10 & 1.035 & 0.4558 & 34 & 1.096 & 0.5119 \\
\hline 11 & 1.854 & 1.2099 & 35 & 1.384 & 0.7771 \\
\hline 12 & 1.635 & 1.0082 & 36 & 0.694 & 0.1418 \\
\hline 13 & 1.214 & 0.6206 & 37 & 1.862 & 1.2173 \\
\hline 14 & 1.465 & 0.8517 & 38 & 1.692 & 1.0608 \\
\hline 15 & 2.472 & $1.7790^{*}$ & 39 & 2.395 & $1.7081^{*}$ \\
\hline 16 & 0.652 & 0.1031 & 40 & 1.427 & 0.8167 \\
\hline 17 & 1.821 & 1.1795 & 41 & 1.396 & 0.7882 \\
\hline 18 & 1.689 & 1.0580 & 42 & 0.874 & 0.3075 \\
\hline 19 & 0.796 & 0.2351 & 43 & 1.625 & 0.9990 \\
\hline 20 & 2.647 & $1.9403^{*}$ & 44 & 2.235 & $1.5607^{*}$ \\
\hline 21 & 1.523 & 0.9051 & 45 & 1.487 & 0.8720 \\
\hline 22 & 1.326 & 0.7237 & 46 & 1.742 & 1.1068 \\
\hline 23 & 0.984 & 0.4088 & 47 & 2.452 & $1.7605^{*}$ \\
\hline 24 & 1.694 & 1.0626 & 48 & 1.884 & 1.2375 \\
\hline
\end{tabular}

Number of seronegative samples $(\%)=40(83.33)$

Number of seropositive samples $(\%)=8(16.67 \%)$.

$\mathrm{S} / \mathrm{P} \geq 1.35$ positive, $<1.35$ negative

* Indicates positive result.

\section{DISCUSSION}

Salmonellosis is considered one of the dangerous zoonotic diseases causing severe economical losses in both human and animal sources. Food poisoning resulting from consumption of food from animal origin contaminated with Salmonella microorganisms, is being one of the emphasizing needs to spotlight upon its prevalence among human and feed.

The obtained results in Table (2) showed that the S.enteritidis was isolated from human stool samples with an incidence of $(12.5 \%)$. This result was nearly similar to the result recorded by Das et al. (1990) 
who recorded that a percent (12\%) of S.enteritidis was isolated from human stool samples. On the other hand, the obtained results were higher than the results recorded by Danish Zoonosis Center (1997) which recorded an incidence $(0.07 \%)$ of SE, this low incidence was mainly due to the higher hygienic measures and lower than the incidence recoded by Kwabata et al. (2006) (70\%), this high incidence because all samples are taken from human suspected salmnellosis outbreaks.

The incidence of S.enteritidis isolated from 30 hand swabs of food handlers was $(13.3 \%)$, this incidence agreed with incidence of Dryden et al. (1994) which was (12.3\%), this proved that improper sanitary measures, and inadequate hand washing or clean may be the cause. The incidence was higher than results obtained by Smith et al. (2009) (5.3\%) in food handlers, their low incidence was good indication for high sanitary measures of these workers. Our result was lower than that recorded by Bailey and Gosby (2005) which was 31\%, and was mainly due to the very low hygienic measures of the workers.

The obtained data revealed that the incidence of S.enteritidis from 100 cloacal swabs was (14\%). This result was of a similar range of results reported by Osman (1992) who isolated S.enteritidis from broiler farms with an incidence (17.8\%). These results may came from contamination during sampling and also may be due to massive use of antibiotic treatment beginning from day-1 of age, which leads to presence of carrier individuals which may harbour the organism with no expressing of signs of a disease. On the other hand, S.enteritidis was isolated with lower incidence by Hui and Das (2001) (4.28\%), Murugkar et al. (2005) (3.64\%) and El-Zeedy et al. (2007) (1.54\%) from live poultry samples. These low incidences of isolation may be due to recently used hygienic control measures used in poultry farms, and the developed methods of rearing of flocks.

The incidence of S.enteritidis in poultry meat was (2\%). Higher results were reported by Jalali et al. (2008) (17.9\%) and Duarte et al. (2009) (9.6\%) in broiler carcasses. This may be due to that poultry meat and its products are liable for contamination from different sources at slaughtering, during its production, handling, packing and storages.

Reported data indicated that incidence of S.enteritidis isolates from 100 frozen beef meat samples were (1\%). This obtained result was low than that reported by Mosupye and Holy (1999) (3.3\%). These results may be due to no proper evisceration occurred to the carcasses or an external contamination occurred from food handlers or an unhygienic handling of meat during its preparation and storage. The incidence of 
S.enteritidis from egg samples was (2\%). This obtained result was to some extent lower than that obtained by Molbak and Neimann (2002) who recorded similar results $(3.4 \%)$ from raw eggs and $(2.5 \%)$ from fried eggs. These results can be explained as collected eggs had transovarian transmission from carrier birds which had no signs of a disease but shedding of S.enteritidis in eggs have been occurred. The incidence of S.enteritidis isolated from raw unpasteurized milk was (12\%). This result was supported by Karns et al. (2005) who recorded a nearly similar incidence (11.8\%) Also, Nero et al. (2009) isolate (9.2\%) from raw unpasteurized milk. This similarity may be due to that the raw milk had been contaminated from utensils, handlers or milkers. However, this obtained incidence was higher than the incidence obtained by Jayarao and Henning (2001) (6.1\%), and this lower incidence may be due to more hygienic measures application during milking and handling. Some other researchers failed to isolate S.enteritidis from milk at all, such as EKici et al. (2004) and Abd El-Aal (2008).

The obtained data showed that incidence of S.enteritidis isolated from ice-cream samples was (8\%). This obtained result was within range but quite higher than obtained incidence by El-Sharef et al. (2005) who recorded an incidence of (5\%) from ice-cream samples. This incidence may be due to that processing and manufacturing of ice-cream was affected by contamination during processing or from food handlers' contaminated hands or contaminated utensils. Our results were higher than the results of Thomas et al. (1996) who recorded a (3\%) incidence as they collected samples from ice-cream manufactured from pasteurized milk and this incidence of isolation may have come from postmanufacture contamination. The reported results showed that S.enteritidis could not be isolated from either yoghurt or soft cheese (Zero \%). These results agreed with results indicated by Borelli et al. (2006); Abd El-Aal (2008) who failed to isolate any Salmonella strain from yoghurt or soft cheese. These results may be due to that the processing of soft cheese occurs when the acidity of milk is increased towards the acid $\mathrm{pH}$ (decreased $\mathrm{pH}$ value) nearly to $\mathrm{pH}$ (4), and this low $\mathrm{pH}$ is a more killer and not suitable for S.enteritidis growth or multiplication. Also, the same manner occurs in yoghurt as high acidity of yoghurt leads to death of the microorganism. On the other hand, some investigators could isolate S.enteritidis such as Yagoub et al. (2006) (6\%) from yoghurt and Colak et al. (2007) (1.5\%) from cheese.

The enzyme linked immunosorbent assay (ELISA) is now widely used to detect antibodies in a variety of test system such assays are 
specific, sensitive and relatively inexpensive to set up. It can offer rapid screening of samples with a negative result available in 24 hours and an early indication of a potential positive result. Results of ELISA revealed that from 48 serum samples of patients suffering from food poisoning, $8(16.67 \%)$ of the examined serosamples were sero-positive (Table 4). The obtained result was somewhat lower than the results of Schneid et al. (2009) who recoded (26\%).

Regarding the antimicrobial sensitivity tests Table(3) using disk diffusion method, to the isolated S.enteritidis strains from the previous sources, showed that ciprofloxacin was the drug of choice followed by enrofloxacin, gentamicin, then neomycin, tetracycline, chloramphenicol, trimethoprim-sulfamethoxazole and the lowest sensitivity was to ampicillin. This results was assured by the results of some researchers such as Duarte et al. (2009) who isolated S.enteritidis from patients with food poisoning symptoms, Murugkar et al. (2005) who showed that all S.enteritidis isolated from poultry, Yagoub et al. (2006) who found that all isolated S.enteritidis from milk and its products, Simth et al. (2009) who found that all isolated S.enteritidis from food handlers was highly sensitive to ciprofloxacin followed by enrofloxacin then chloramphinicol and low sensitive to gentamicin, trimethoprim- sulfamethoxazole but highly resistant to ampicillin.

\section{REFERENCES}

Abd El-Aal, S.F.A. (2008): Microbiological research on some dairy product. Assiut Vet. Med. J., 54 (119): 54-64.

Ashton, W.L.G. (1990): Enterobacteriaceae in poultry disease (Edition Jordan F.T.). $3^{\text {rd }}$ Ed., El Bs/Baunere: 11-41.

Bailey, J.S. and Gosby, D.E. (2005): Salmonella prevalence in freerange and certified organic chickens. J. Food Protec., 68 (11): 2451-2453.

Barrow, P.A. (1994): Proceedings of EU workshop on ELISAs for serological diagnosis of Salmonella infections in poultry. Brussels. 7-9 June, Europena Commission.

Borelli, B.M.; Ferreira, E.G.; lacerda, C.A.; Santos, D.A.; Carmo, L.S.; Dias, R.S.; Silva, M.C.C. and Rosa C.A. (2006): Enterotoxigenic Staphylococcus species and other microbial contaminants during production of cheese,Brazilian J. Microbiol., 37: 545-550. 
Colak, H.; Hampikyan, H.; Bingol, E.B. and Ulusoy, B. (2007): Prevalence of L. monocytogenes and Salmonella species in Tulum cheese. Food Control, 18: 576-579.

Cruickshank, R.; Duguid, J.P.; Marmion, B.P. and Swain, R.H.A. (1975): Medical Microbiology. The Practice of Medical Microbiology. $12^{\text {th }}$ Ed. Vol. II Churchill Living stone, Edinburgh, London and New York.2: 170-188.

Danish Zoonosis Center, Annual report on zoonoses in Denmark (1997):

Copenhagen, Denmark, Danish zoonosis center 1997 (http.//zoonyt.dz.dk/annualreport1997/index.html)

Das, M.S.; Roy, D.K. and Das, S. (1990): Occurrence of salmonellae in slaughtered pigs, goat meat, meat handlers and slaughtered house workers. J. Commun. Dis., 22 (1): 39-42.

Dryden, A.S.; Keyworth, N.; Gab, R. and Stin, K. (1994): Asymptomatic food handlers as the source of nosocomial Salmonellosis. J. Hosp. Infect., 28(3): 195-208.

Duarte, D.A.M.; Ribeiro, A.R.; Vasconcelos, A.M.M.; Santos, S.B.; Silva, J.V.D.; Andrade, P.L.A. and Falcao, C.A. (2009): Occurrence of Salmonella species in broiler chickens carcasses and their susceptibility to antimicrobial agents. Braz. J. Microbiol., 40(3): 569-573.

Ekici, K.; Bozkurt, H. and Isleyici, O. (2004): Isolation of some pathogens from raw milk of different animal. Pakistan J. Nutrit.., 3 (3): 161-162.

El-Sharef, N.; Ghenghesh, K.S.; Abognah, Y.S.; Gnan, S.O. and Rahouma, A. (2005): Bacteriological quality of ice cream in Tripoli- Libya., Food. Contr. 17: 637-641.

El-Zeedy, S.A.; Eldeen, H.K. and Badr, G.M. (2007): Protein analysis for comparison between Salmonellae isolated from different poultry species. BS. Vet. Med. J., 17 (2): 1-9.

Fantasia, M. and Filetici, E. (1994): Salmonella enteritidis in Italy. Int. J. Food Microbiol., 12:7-13.

Finegold, S.M. and Martin, E.T. (1982): Diagnostic Microbiology. $6^{\text {th }}$ Ed., The C.V. Mosby Company, St. Louis, Toronto, London.

Hassan, J.O.; Barrow, P.A.; Mockett, A.P. and Mcleod, S. (1990): Detection of salmonella typhymurium $\ln$ chickens by indirect ELISA Vet. rec.126: 519-522.

Hui, A.K. and Das, R. (2001): Studies on isolation, serotyping and antibiotic sensitivity of Salmonella isolated from ducks. Ind. Vet. J., 78 (11): 1058-1059. 
Jalali, M.; Abedi, D.; Pourbakhsh, S.A. and Ghokasin, K. (2008): Prevalence of Salmonella species in raw and cooked foods in Isfahan, Iran. J. of Foods Safety, 28 (3): 442-452.

Jayarao, B.M. and Henning, D.R. (2001): Prevalence of food borne pathogens in bulk tank milk. J. Dairy Sci., 84 (10): 2157-2162.

Karns, J.S.; Vankessl, J.S.; McCluskey, B.J. and Perude, M.L. (2005):

Prevalence of Salmonella enterica in bulk tank milk from dairies as determined by polymerase chain reaction. J. Dairy Sci., 88(10): 3475-3479.

Kauffman, F. (1974): Serological diagnosis of Salmonella species. Kauffman White Scheme Minkagaord, Copenhagen, Denmark.

Kawabata, A.; Ishikawa, K.; Iwasaki, Y.; Aoki, K.; Takagi, S.; Namikawa, T.; Ohtomo, K. and Inoue, T. (2006): Food poisoning outbreaks of Salmonella enteritidis caused by Box Lunch in Shiga Prefecture, Japan. Jpn. J. Infect. Dis., 59: 406-407.

Molbak, K. and Neimann, J. (2002): Risk factors for sporadic infection with Salmonella enteritidis, Denmark, 1997-1999. Am. J. Epidemiol., 156 (7): 654-661.

Mosupye, M.F. and Holy, V.A. (1999): Microbiological quality and safety of ready to eat street vended food in Johannesburg, South Africa. J. Food Prot., 62 (11): 1278-1284.

Murugkar, H.V.; Rahman, H.; Kumar, A. and Bhattacharya (2005): Isolation, phage typing and antibiogram of Salmonella from man and animals in northeastern India. Indian J. Med. Res., 122: 237-242.

Nero, L.A.; Mattos, M.R.; Beloti, V.; Barros, M.A.F.; Ortolani, M.B.T. and Franco, B.D. (2009): Autochthonous microbiota of raw milk with antagonistic activity against Listeria monocytogenes and Salmonella enteritidis. J. Food Safety, 29 (2): 261-270.

Osman, M.M. (1992): Studies on bacterial causes of early poultry mortality in Sharkia Governorate. M.V.Sc. Thesis (Bacteriology) Faculty of Veterinary Medicine, Zagazig University.

Schneid, A.S.; Rodrigues, K.L.; Chemello, D.; Tondo, E.C.; Ayub, M.A.Z. and Aleixo, J.A.G. (2009): Evaluation of an indirect ELISA for the detection of Salmonella. Braz. J. Microbiol., 37: 350-355. 
Smith, S.I.; Bamidele, M.; Goodluck, H.A.; Fowora, M.N.; Omonigbehin, E.A.; Opere, B.O. and Aboaba, O.O. (2009): Antimicrobial susceptabilities of Salmonellae isolated from food handlers and cattle in Lagos, Nigeria. Internat. J. health Res., 2 (2): 189-193.

Thomas, W.; Craig, W.H.; Laurence, S. and Karen, E.W. (1996): A national outbreak of Salmonella enteritidis infections from ice cream. New England J. med., 334 (20): 1281-1286.

Yagoub, S.O.; Oshi, N.A.M. and El-Zubeir, I.E.M. (2006): Isolation and susceptibility of antimicrobial agents of Salmonella species from cheese in Khartoum (Sudan). Res. J. Microbiol., 1 (2): 110-114.

Zhu, C.H.; Hassan, H.; Musa Wu S.L. and Zhu, G.Q. (2009): The role of SEF14 fimbriae in pathogenesis and enhancing the immunity of Salmonella enteritidis. African J. Microbiol. Res., 3(5): 191-194. 